\begin{tabular}{|c|c|c|c|}
\hline \multirow{2}{*}{$\begin{array}{l}\text { KULTURA } \\
\text { i } \\
\text { SPOLECLENS }\end{array}$} & \multicolumn{2}{|c|}{$\begin{array}{l}\text { POLSKA AKADEMIA NAUK } \\
\text { KOMITET SOCJOLOGII } \\
\text { INSTYTUT STUDIÓW POLITYCZNYCH }\end{array}$} & \multirow[t]{2}{*}{ ISSN 0023-5172 } \\
\hline & 2011, nr 4 & PRZESZŁOŚĆ I PAMIĘĆ & \\
\hline
\end{tabular}

CHRISTIAN GUDEHUS, HARALD WELZER

Center for Interdisciplinary Memory Research $w$ Essen

\title{
O METODZIE I TEORII BADAŃ NAD PRZEKAZEM KULTUROWYM*
}

Kwestie związane $z$ historią i konstruowaniem obrazów przeszłości zawsze miały wielkie znaczenie dla samoidentyfikacji jednostek, grup społecznych, instytucji władzy, państw i narodów. Widać to szczególnie wyraźnie w przełomowych momentach, gdy władcze ambicje i mechanizmy stabilizowania władzy wyłaniają się z „wynalezionych” bądź „odnalezionych” tradycji, znajdując oparcie w na nowo skonstruowanej historii ${ }^{1}$. Obecnie można zauważyć dwie pozornie przeciwstawne, lecz $\mathrm{w}$ gruncie rzeczy nawzajem się warunkujące i kształtujące tendencje. Pierwszą $z$ nich jest renegocjowanie i redefiniowanie narodowych narracji historycznych, drugą natomiast otwieranie się historiografii narodowej na perspektywę transnarodową lub zglobalizowaną ${ }^{2}$.

Nowa ocena drugiej wojny światowej, czasów okupacji, kolaboracji i ruchu oporu należy do głównych tematów debat publicznych toczonych w wielu społeczeństwach europejskich. Fakt, że ostatecznie wszystkie społeczeństwa zachodnioeuropejskie stały się społeczeństwami napływowymi, odbija się na kulturach pamięci, w których coraz większą rolę odgrywają aspekty transnarodowe. Społeczeństwa Europy Zachodniej mają już za sobą ponad 65 lat powojennej historii, która stała się przedmiotem uhistorycznienia w postaci dyskursów przezwyciężania i rozpracowywania, innymi słowy — „historii pamięci”.

Adres do korespondencji: christian.gudehus@uni-flensburg.de; harald.welzer@kwi-nrw.de

*Artykuł ukaże się też w: Polsko-niemieckie miejsca pamięci, Robert Traba, Hans Hennig Hahn (red.), Warszawa [2012], t. 4: Refleksje metodologiczne.

${ }^{1}$ Eric Hobsbawm, Wprowadzenie. Wynajdywanie tradycji, w: Tradycja wynaleziona, Eric Hobsbawm, Terence Ranger (red.), tłum. Mieczysław Godyń, Filip Godyń, Kraków 2008, s. 1-14; Florian Fiedler, Bildersturm in Osteuropa, München 1995.

2 Daniel Levy, Natan Sznaider, Erinnerung im globalen Zeitalter. Der Holocaust, Frankfurt am Main 2001. 
W efekcie rozwinęly się między innymi metanarracje, czyli opowiadanie o opowiadaniu, które często nakładały się na historię wojny i masowych zbrodni. $\mathrm{Z}$ kolei społeczeństwa wschodnioeuropejskie, jako społeczeństwa $\mathrm{w}$ stanie transformacji per se, mają ogromne potrzeby w zakresie samoidentyfikacji, poszukują integrującej historii, przy czym warto odnotować fakt, że często to opowieści ofiar wyznaczają - jak się wydaje — kierunek owych poszukiwań. W społeczeństwach zachodnioeuropejskich, które we własnym przekonaniu nie doświadczyły tak głębokiej transformacji, zwiększona potrzeba samoidentyfikacji opartej na przeszłości wynika raczej z głębokiej niepewności co do przyszłości.

W trudnej do przeniknięcia strukturze powstają „transnarodowe przestrzenie pamięci", co wskazuje na brzemienne w skutki oddziaływanie horyzontalnych procesów europeizacji ${ }^{3}$. Państwo narodowe nie może być już „oczywistym" punktem odniesienia dla historiografii i kultury historycznej, ponieważ nie zadowala dotyczących tożsamości i samoidentyfikacji potrzeb uczennic i uczniów pochodzących z różnych krajów. Szkoła i media mają bowiem niewiele do zaoferowania młodzieży o pochodzeniu imigranckim $\mathrm{w}$ dziedzinie przekazywania kultury narodowej, dzięki której powstaje świadomość historyczna budująca poczucie przynależności. Jednocześnie zwraca się uwagę na „globalizację pamięci” i konsekwencje integracji europejskiej dla kultur historycznych i przekazu historii. Narodowe obrazy i mity historyczne w ograniczonym zakresie działają integrująco na członków europejskich społeczeństw. Jak pokazują „miejsca pamięci” różnych narodów - nader wątpliwe ${ }^{4}$ jest ich znaczenie dla $\mathrm{w}$ wysokim stopniu normatywnie zorientowanych struktur tak zwanej tożsamości europejskiej opartej na jeszcze mniej wiarygodnej pamięci europejskiej ${ }^{5}$, zapośredniczonej przez również normatywnie zorientowane projekty publicystyczne.

W tym nieprzejrzystym gąszczu ukształtował się kierunek badawczy, który nie zajmuje się publicznymi aspektami kultury i polityki pamięci, lecz subiektywnymi sposobami przyswajania i wykorzystywania przeszłości. Kierunkiem tym są badania nad tradycją i jej przekazem.

Niemieckie słowo tradieren rozumie się zwykle jako „przekazywać”* Jest ono powszechnie stosowane w odniesieniu do przekazywania zacho-

\footnotetext{
3 Ulrich Beck, Edgar Grande, Europa kosmopolityczna. Społeczeństwo i polityka w drugiej nowoczesności, tłum. Aleksander Ochocki, Warszawa 2009.

${ }^{4}$ Por. krytykę normatywnego charakteru koncepcji i jej skłonności do wykluczania Jens Kroh, Anne-Katrin Lang, Erinnerungsorte, w: Erinnerung und Gedächtnis. Ein interdisziplinäres Handbuch, Christian Gudehus, Ariane Eichenberg, Harald Welzer (red.), Stuttgart 2010, s. 184-188.

${ }^{5}$ Europas Gedächtnis. Das neue Europa zwischen nationalen Erinnerungen und gemeinsamer Identität, Helmut König, Julia Schmidt, Manfred Sicking (red.), Bielefeld 2008.

${ }^{*}$ Niemieckie słowo Tradierung (Tradierungsvorgänge, Tradierungsforschung) nie ma w języku polskim odpowiednika $\mathrm{w}$ pełni oddającego jego treść. Redakcja zdecydowała się zastosować w przekładzie, w zależności od kontekstu, określenia „przekaz pamięci”, „transmisja” — przyp. red.
} 
wań bądź czynności (na przykład obyczajów i rytuałów), wiedzy praktycznej (na przykład sztuki budowlanej, sztuki lekarskiej) oraz wartości, przede wszystkim jednak wiedzy o przeszłości, która również - a może przede wszystkim - przekazywana jest w postaci licznych historii. Powstają przy tym specyficzne obrazy dziejów zarówno grupy „swoich” [Wir-Gruppe] w węższym znaczeniu, jak i grupy własnej w szerszym znaczeniu, czyli na przykład narodu. Badania nad tradycją i jej przekazem z reguły dotyczą zatem czegoś więcej niż tylko przekazu epizodów z przeszłości oraz dat i faktów tej przeszłości dotyczących. Przekazywane są bowiem jednocześnie interpretacje, struktury i sposoby wykorzystywania przeszłości.

\section{PRE-HISTORIA}

Badania nad tradycją i jej przekazem nie są dyscypliną naukową ani szkołą, nie mają oparcia instytucjonalnego w czasopismach, katedrach uniwersyteckich ani instytucjach badawczych odwołujących się do nich w nazwie ${ }^{*}$. Jest to raczej koncepcja teoretyczno-metodologiczna, która ukształtowała się w toku badań jako odrębne podejście do kluczowej czynności ludzkiej, czyli o powiadania przeszłości. Chodzi o niezwykle użyteczną koncepcję heurystyczną, o sposób myślenia i działania, który w Niemczech wykształcił się w obszarze badań nad świadkami historii i krytyki owych badań, a także związku z oral history i biografistyką, bez których byłby w ogóle nie do pomyślenia. W tej koncepcji nie chodzi ani o rekonstrukcję historii życiowych, ani o często pojawiające się w dziedzinie kultur pamięci aspiracje terapeutyczne (np. „dzieci wojny”, „Second Generation Trust” i inne).

Koncepcyjnie badania nad tradycją i jej przekazem nawiązują do inspirowanej kulturoznawczo teorii pamięci ${ }^{6}$, przede wszystkim do badań nad pamięcią odwołujących się do zdobyczy psychologii społecznej ${ }^{7}$. Oba kierunki badawcze rozwinęły się już w pierwszym ćwierćwieczu XX stulecia. Niemal $\mathrm{w}$ tym samym czasie do uderzająco podobnych wniosków doszli - całkowicie innymi drogami metodologicznymi i w nawiązywaniu do zupełnie odmiennych paradygmatów teoretycznych — socjolog Maurice Halbwachs (1877-

\footnotetext{
* Na Uniwersytecie Warszawskim istniał do niedawna Ośrodek Badań nad Tradycją Antyczną w Polsce i Europie Środkowo-Wschodniej (OBTA UW), który w 2008 r. przemianowano na Instytut Badań Interdyscyplinarnych „Artes Liberales” (BI AL). Ponadto jesienią 2010 r. na Uniwersytecie im. Adama Mickiewicza w Poznaniu założono Pracownię Badań nad Tradycją Europejską. Wprawdzie polskie placówki badawcze wychodzą z innych założeń teoretycznych i metodycznych, ale one również odwołują się do pojęcia badań nad tradycją — przyp. red.

${ }^{6}$ Harald Welzer, Das kommunikative Gedächtnis. Eine Theorie der Erinnerung, München 2002; Astrid Erll, Kollektives Gedächtnis und Erinnerungskulturen, Stuttgart 2005.

7 Hans J. Markowitsch, Harald Welzer, Das autobiographische Gedächtnis. Hirnorganische Grundlagen und biosoziale Entwicklung, Stuttgart 2005.
} 
-1945) oraz psycholog (społeczny) Frederic Bartlett (1886-1969). Stwierdzili oni, że pamięć indywidualna jest konstrukcją społeczną. Kluczową rolę w jej konstruowaniu odgrywają ramy kulturowe (na przykład chłopi lepiej pamiętają skup bydła i oferowane zań ceny niż osoby postronne; to samo dotyczy architektów i form geometrycznych) ${ }^{8}$, funkcje orientacyjne (na przykład historie, które mogą tworzyć sens i związek) oraz skrypty kulturowe (sposoby opowiadania, struktury fabularne i wyobrażenia o racjonalności). Ponieważ pamięć jest zawsze funkcją teraźniejszości, a przeszłość interpretuje się pod dyktando potrzeb przyszłości, to, co jednostki i zbiorowości uważają za swoją przeszłość, tylko po części wyglądało tak, jak to się odtwarza, a przede wszystkim przekazuje dalej — zarówno jako historię, jak i w historiach.

Z tych założeń wynikają dwa sposoby patrzenia na opowiadania o przeszłości. Pierwszy z nich polega na zainteresowaniu tym, co zdarzyło się nap raw dę w świetle różnych sprawdzonych źródeł informacji, przy czym zauważalne, wymierne odchylenia interpretuje się jako deformację, błędy bądź przeinaczenia pamięci ${ }^{9}$. Jest to naukowa rekonstrukcja przeszłości, choć i tu od kilku dziesięcioleci podnosi się zarzuty, których autorzy wskazują na konstruktywistyczny i „poetycki” charakter narracji historycznych ${ }^{10}$. Drugi sposób patrzenia, właściwy badaniom nad tradycją i jej przekazem, polega na skupieniu się na społecznych, specyficznych historycznie i kulturowo konstrukcjach minionych zdarzeń, i ich interpretacji ze względu na użyteczność w zakresie spełniania wymagań teraźniejszości. W tej perspektywie bada się, co, jak i dlaczego jest opowiadane. Jest to złagodzona wersja dziedzictwa postmodernistycznych teorii reprezentacji, w myśl których historię i historie interpretuje się jako efekt narracyjnych tradycji, a więc jako formy upoetyczniania przeszłości ${ }^{11}$. Wbrew założeniu, które zbyt często przyjmuje się $z$ intencją polemiczną, nie ma tu wcale mowy o relatywizacji minionych zdarzeń, na przykład zbrodni popełnionych przeciwko społeczeństwu. Wręcz przeciwnie: znajomość zasad konstrukcji opowieści o przeszłości umożliwia znaczne zróżnicowanie form krytyki źródeł, zwłaszcza w odniesieniu do nie popartych świadectwami opowiadań, takich jak relacje świadków.

\footnotetext{
8 Frederic Bartlett, Remembering: A Study in Experimental and Social Psychology, Cambridge 1997 [1932], s. 21, 249-251.

${ }_{9}$ Rüdiger Pohl, Das autobiographische Gedächtnis, w: Erinnerung und Gedächtnis, cyt. wyd., s. 75-84 .

10 Hayden White, Metahistory: The Historical Imagination in Nineteenth-Century Europe, Johns Hopkins University Press, Baltimore 1973; Kenneth J. Gergen, Social Construction in Context, Sage, London 2001.

11 Christian Gudehus, Erinnern, Erzählen, Überliefern. Familiengeschichte im Lichte der Tradierungsforschung, w: Individualisierung von Geschichte. Neue Chancen für die Archive?, Peter Müller (red.), Stuttgart 2008, s. 12.
} 


\section{STUDIA}

Paradygmatycznym tematem badań nad pamięcią w Niemczech przez długie lata był kompleks zagadnień, na który składały się narodowy socjalizm, druga wojna światowa, Holokaust $\mathrm{i}$ - związane $\mathrm{z}$ nimi - przepracowywanie albo opracowywanie tego okresu. Niemal wszystkie studia poświęcone przekazywaniu przeszłości skupiają się na tych czasach. Przez długi czas publicznie, oficjalnie zajmowano się "przeszłością negatywną" ${ }^{12}$, czyli zasobami wiedzy i interpretacjami, które determinują dyskursy, ale $\mathrm{w}$ połowie lat dziewięćdziesiątych XX wieku wielu badaczy-empiryków zaczęło się interesować sposobami odczytywania zdarzeń historycznych oraz związkami zachodzącymi w prywatnej sferze wspólnot pamięci, na przykład w obrębie rodziny. W kolejnych latach powstawały zatem studia poświęcone opowiadaniu o przeszłości, a ich autorzy przede wszystkim brali pod uwagę przedstawicieli różnych generacji i analizowali to opowiadanie na różne sposoby. Na przykład Gabriele Rosenthal prześledziła sposoby opowiadania o narodowym socjalizmie i Holokauście w rodzinach prześladowców i prześladowanych. Jej celem było odkrycie „ukrytych biograficznych struktur sensu" 13 oraz skupienie się na biograficznej i rodzinnej (systemowej) funkcji opowieści biograficznych ${ }^{14}$. Z kolei Ninę Leonhard szczególnie zainteresował związek między świadomością historyczną i polityczną ${ }^{15}$. Friedhelm Boll zbadał funkcję opowiadania w przypadku byłych prześladowanych oraz wpływ koniunktur społecznych w obszarze tematyzowania przeszłości na możliwość opowiadania ${ }^{16}$. Michael Kohlstruck skonstruował typy problematyzowania przeszłości narodowosocjalistycznej przez przedstawicieli roczników 1951-1967 jako sposobu prywatnego przezwyciężania przeszłości ${ }^{17}$. Viola Georgi zbadała, jak odnajdują się $\mathrm{w}$ tej historii żyjący w Niemczech młodzi ludzie (między 15 i 20 rokiem życia) o imigranckim pochodzeniu. Ponadto wyróżniła typy związków z histo-

\footnotetext{
12 Reinhart Koselleck, Formen und Traditionen des negativen Gedächtnisses, w: Verbrechen erinnern. Die Auseinandersetzung mit Holocaust und Völkermord, Volkhard Knigge, Norbert Frei (red.), München 2002, s. 21-32.

13 Gabriele Rosenthal, Fragestellung und Methode, w: Der Holocaust im Leben von drei Generationen. Familien von Überlebenden der Shoah und von Nazi-Tätern, Gabriele Rosenthal (red.), Gießen 1997, s. 12 .

14 Gabriele Rosenthal, Trennende und bindende Vergangenheiten. Zur familienbiographischen Arbeit und Dynamik in Ehen zwischen Nachkommen und Überlebenden der Shoah und von Nazi-Tätern, w: Die Gegenwart der Geschichte des Holocaust. Intergenerationelle Tradierung und Kommunikation der Nachkommen, Christian Staffa, Katharina Klinger (red.), Berlin 1998, s. 17-46.

${ }^{15}$ Nina Leonhard, Politik- und Geschichtsbewusstsein im Wandel. Die politische Bedeutung der nationalsozialistischen Vergangenheit im Verlauf von drei Generationen in Ost- und Westdeutschland, Münster 2002.

16 Friedhelm Boll, Sprechen als Last und Befreiung. Holocaust-Überlebende und politisch Verfolgte zweier Diktaturen, Bonn 2003.

17 Michael Kohlstruck, Zwischen Erinnerung und Geschichte. Der Nationalsozialismus und die jungen Deutschen, Berlin 1997.
} 
rią $^{18}$. Grupa badaczy skupionych wokół Haralda Welzera w dwóch studiach, które stały się podstawą dla wielu monografii, podjęła próbę zbadania przekazu w obrębie rodzin historii narodowego socjalizmu i drugiej wojny światowej ${ }^{19}$. Ten rodzaj studiów międzypokoleniowych podlega umiędzynarodowieniu ${ }^{20}$.

Jak pokazuje powyższe zestawienie, chodzi tu bez wyjątku o badania osadzone $\mathrm{w}$ tradycji jakościowych badań socjologicznych, $\mathrm{z}$ reguły oparte na wywiadach. Welzer i jego współpracowniczki przeprowadzili wywiady z członkami rodzin reprezentującymi trzy pokolenia (pokolenie, które przeżyło narodowy socjalizm, jego dzieci i wnuki) i zestawili je z rozmowami między członkami całej rodziny, aby zobaczyć, jakie interakcje zachodzą w obrębie rodziny, porównać wersje historii opowiedzianych przez poszczególnych członków rodzin i skonfrontować je $z$ rodzinnymi rozmowami. Wychodząc z założenia, że wszyscy uczestnicy rozmów, a więc także przeprowadzający wywiady, biorą komunikacyjnie udział $\mathrm{w}$ konstruowaniu opowieści, właśnie ten aspekt poddano analizie przy użyciu rozwiniętej przez Haralda Welzera „hermeneutycznej analizy dialogu". Ta kluczowa dla badań nad tradycją procedura umożliwia - o czym się dziś często zapomina - śledzenie procesu „wspólnego tworzenia” opowieści o przeszłości. Przekonania, że świadomość historyczna jest czymś, co tkwi w ludziach głęboko i trzeba to $z$ nich wydobywać za pomocą arsenału odpowiednich metod, nie można potwierdzić empiryczne. Tworzenie interpretacji historii, tak jak kreowanie poglądów, jest procesem w najwyższym stopniu komunikacyjnym, a przez to społecznym. Narracje powstają w sytuacyjnych i komunikacyjnych settings przy udziale - choć często asymetrycznym - wszystkich osób uwikłanych w daną sytuację. Dzieje się tak nawet wtedy, gdy osoby te są tylko słuchaczami. Przemówienie, wykład, opowiadanie przewodnika oraz analiza wytwarzają rozmaite formy dramatyczne, sposoby opowiadania i tematyczne punkty ciężkości.

Kolejnym zauważalnym efektem jest zjawisko nazwane „kumultywną heroizacją". Oznacza ono reinterpretację problematycznych z dzisiejszego punktu widzenia opowiadań pokolenia przeżywającego, sugerujących antysemityzm, rasizm, a nawet zbrodnię. W wywiadach $\mathrm{z}$ jego dziećmi, zwłaszcza zaś $\mathrm{z}$ wnukami, te opowieści albo są pomijane albo przekształcane w opowiadania o oporze wobec tych zjawisk. Ważną przyczyną tego potwierdzonego przez badania

\footnotetext{
18 Viola B. Georgi, Entliehene Erinnerung. Geschichtsbilder junger Migranten in Deutschland, Hamburg 2003.

${ }^{19}$ Harald Welzer, Robert Montau, Christine Plaß, „Was wir für böse Menschen sind!” Der Nationalsozialismus im Gespräch zwischen den Generationen, Tübingen 1997; Harald Welzer, Sabine Moller, Karoline Tschuggnall, Opa war kein Nazi. Nationalsozialismus und Holocaust im Familiengedächtnis, Frankfurt am Main 2002; por. Piotr Tadeusz Kwiatkowski, Lech M. Nijakowski, Barbara Szacka, Andrzej Szpociński, Między codziennościa a wielka historią. Druga wojna w pamięci zbiorowej społeczeństwa polskiego, Warszawa 2010.

20 Erzählte Zukunft. Zur inter- und intragenerationellen Kommunikation über Zukunftserwartungen, Jens Kroh, Sophie Neuenkirch (red.), Göttingen 2011.
} 
ilościowe zjawiska jest zniesienie dysonansów poznawczych. Obraz ożywianych pozytywnymi emocjami członków rodzin - ewentualnie wizerunek rodziny, jaki pragną stworzyć mówiący - z trudem można pogodzić z obrazem „nazisty” przekazywanym kanałami edukacyjnymi i informacyjnymi. Wspomniana reinterpretacja, podobnie zresztą jak opowiadania autobiograficzne, nie odbywa się bez intencji, lecz wynika $z$ dążenia do interpretacji przeszłości odpowiadającej współczesnym potrzebom sensu i orientacji. $\mathrm{W}$ tej przemianie historii zgodnie $z$ potrzebami sensu i klarowności tych, którzy je ponownie opowiadają, tkwi sedno tego, co nazywa się przekazywaniem.

„To, co nazywamy przekazywaniem, wymaga aktywnego przyswojenia relacjonowanych treści, czyli przekazywane historie wymagają punktu zaczepienia we własnym życiu [...]; jest to forma narracyjna, która zostawia przestrzeń dla uzupełnień oraz sytuacja narracyjna, która sama w sobie stanowi przeżycie [...]. Pod tymi warunkami opowieść staje się przekazywalna, to znaczy z opowieści obcej staje się opowieścią własną" 21 .

Ponowne opowiadanie świadczy więc o tym, że występuje przekaz. Istotą tego, co opisuje pojęcie przekazu, jest zatem recepcja w znaczeniu nowej, własnej i przyswojonej relacji. Wynika z tego, że każda opowieść o przeszłości z punktu widzenia teorii komunikacji jest zawsze początkiem i końcem łańcucha przekazu. Każda opowieść opiera się na opowiadaniach, i to na wielu opowiadaniach. Indywidualne interpretacje powstają $\mathrm{w}$ wielu procesach komunikacyjnych i dlatego, przynajmniej teoretycznie, ich zmienność jest nieograniczona. Każda opowieść jest więc punktem wyjścia do nowych opowieści. Jeśli zabraknie tego punktu wyjścia, czyli nowo przyswojonej opowieści, to łańcuch ulegnie zerwaniu i przekaz nie nastąpi. Dotyczy to również relacji pokolenia przeżywającego. Jak wiadomo $z$ psychologicznych badań pamięci, wspomnienia tylko częściowo są oparte na własnych przeżyciach; pamięć autobiograficzna może być w poważnym stopniu fikcyjna bądź zfikcjonalizowana ${ }^{22}$. Każda opowieść odwołuje się do wielu źródeł - wybór i połączenie detali wynikają z uwarunkowań komunikacyjnych występujących w konkretnej sytuacji oraz z psychologicznych i społecznych potrzeb osób opowiadających.

Opowieści nadal podlegają zasadom logiki dramaturgicznej, które - jak wiadomo dzięki studiom Frederica Bartletta - mają swoją specyfikę kulturową. Historie uprawdopodobnia się $\mathrm{w}$ takim stopniu, że stają się one zgodne z wyobrażeniami, jakie mają o sobie osoby opowiadające, bądź z ich wyobrażeniami o innych oraz z aktualnymi „skryptami kulturowymi” ${ }^{23}$. Te wszystkie aspekty decydują o tym, co i jak jest wspominane, opowiadane, opowiadane po-

\footnotetext{
${ }^{21}$ Harald Welzer, Sabine Moller, Karoline Tschuggnall, Opa war kein Nazi, cyt. wyd., s. 35.

22 Hans J. Markowitsch, Harald Welzer, Das autobiographische Gedächtnis. Hirnorganische Grundlagen und biosoziale Entwicklung, Stuttgart 2005, s. 28-30.

23 Robyn Fivush, Remembering and Reminiscing: How Individual Lives are Constructed in Family Narratives, „Memory Studies” 2008, t. 1, z. 1, s. 51-52.
} 
nownie i przez to także przekazywane. Badania empiryczne ujawniają wysoki stopień formatywności opowieści o przeszłości w postaci idealnych „typów transmisji". Chodzi o sposoby dramatyzowania przeszłości, które opierają się na tradycyjnych skryptach. W odniesieniu do przekazu niemieckiego sposobu interpretowania narodowosocjalistycznej przeszłości były to: „bycie ofiarą”, „usprawiedliwienie”, „zdystansowanie”, „fascynacja” i „bohaterstwo” 24. Pokazują one, w jaką formę zostanie ujęta przeszłość podczas rozmowy. Przekazywane są zatem - już to jako drobna uwaga, już to jako wielka, obejmująca całą biografię opowieść - interpretacje, które często opierają się na toposach i wzorcach interpretacyjnych.

\section{TOPOSY I WZORCE INTERPRETACYJNE}

Toposy są słowami, które poza swym pierwotnym znaczeniem zawierają interpretacje, a tym samym także klasyfikacje. W opowiadaniu o narodowym socjalizmie topos dominujący to „naziści”. Są to ci, którzy rozpętali wojnę, prześladowali i mordowali Żydów, a także zbudowali i prowadzili obozy koncentracyjne. Tworzą oni bliżej nieokreśloną grupę osób odpowiedzialnych za całe zło w przeszłości. Równoczesność klarowności (oto odpowiedzialni) i niejasności (kto właściwie był „nazistą”?) jest charakterystyczna dla wielu podobnych toposów. Właśnie nieostrość i wieloznaczność z toposu takiego jak „naziści” czyni kluczowy element przekazywanych historii. Umowna zgoda co do jego właściwego rozumienia poszczególnym uczestnikom pozwala połączyć własną interpretację z pozornie tą samą historią. Znów widać wyraźnie, że przekaz zawiera - oprócz wersji przeszłości (co się zdarzyło, kiedy, jak, w jakich warunkach i z jakich powodów?) - także historycznie i kulturowo specyficzne oceny, interpretacje i sposoby opowiadania.

Przez „wzorce interpretacyjne” należy rozumieć rozpowszechnione, a więc regularnie spotykane interpretacje minionych zdarzeń, mogące przybierać różne formy językowe. Te interpretacje niekoniecznie są przekazywane intencjonalnie. Ich przekaz często następuje mimochodem, na przykład gdy mówi się o „złym i niebezpiecznym Rusku”, o „niedobrych czasach”, w których przyszło żyć, albo o „bogatych Żydach, którzy nagle zniknęli”. Jak zauważa Georg Bollenbeck, „badanie wbudowanego w język wzorca interpretacyjnego kładzie nacisk na nastawienia zbiorowe zamiast indywidualnych i postnaukowe zamiast naukowych" 25 . Zgodnie $z$ tym poglądem wzorce interpretacyjne i toposy świadczą o istnieniu w opowiadaniu na dowolny temat jakiegoś elementu kolektywnego. Dokładnie w tym miejscu badania nad tradycją i jej przekazem

\footnotetext{
24 Olaf Jensen, Geschichte machen. Strukturmerkmale des intergenerationellen Sprechens über die NS-Vergangenheit in deutschen Familien, Tübingen 2004.

25 Georg Bollenbeck, Bildung und Kultur. Glanz und Elend eines deutschen Deutungsmusters, Frankfurt am Main 1996, s. 20.
} 
nawiązują do podstawowej kwestii w obrębie nauk społecznych, czyli związku między jednostką a zbiorowością (zależnie od teoretycznej proweniencji może być też mowa o kulturze, społeczeństwie bądź strukturze). Mamy tu do czynienia $z$ drugą dialektyczną sprzecznością $\mathrm{w}$ obrębie badań nad procesami przekazu. Pierwsza sprzeczność dotyczyła faktu, że opowieści są zawsze początkiem i końcem procesów przekazu. Druga dialektyczna sprzeczność polega na tym, że wzorce interpretacyjne i toposy, które - tak samo jak skrypty kulturowe - preformują opowiadanie, myślenie, postrzeganie i interpretowanie, same są nieustannie stwarzane przez opowiadanie. Teoretycznie zawsze istnieje możliwość, przynajmniej stopniowego, wypracowania autonomii w stosunku do interpretacji. Każde odstępstwo od wzorców narracyjnych, każdą dekonstrukcję toposów i wzorców interpretacyjnych można więc $z$ tej perspektywy interpretować jako przejaw wolności.

\section{KONTEKSTUALIZACJA}

Oprócz treści (co się zdarzyło?) i struktury (jak się opowiada?) zasadniczymi elementami transmisji są zaangażowanie, zaistnienie, wykorzystanie i kontekstualizacja związku z historią. Kiedy, jak i o jakiej przeszłości jest mowa? Jak na przykład używa się określenia „nazista”? Kiedy porównania są właściwe, a kiedy nie? Sabine Moller, autorka studium na temat publicznych kultur pamięci i rodzinnych wspomnień o czasach narodowego socjalizmu w Niemczech Wschodnich, opisuje, że gdy w 1999 r. Niemcy z Zachodu przeprowadzali wywiady ze swymi ziomkami ze Wschodu, to zamiast oczekiwanych opowieści o narodowym socjalizmie, usłyszeli historie o wiele dla rozmówców ważniejsze, bo dotyczące ich doświadczeń z czasów NRD. Były to opowieści o cenzurze i o społecznej kontroli za pośrednictwem takich organizacji jak FDJ. Respondenci wskazywali przy tym na strukturalnie porównywalne elementy narodowego socjalizmu, takie jak organizacje młodzieżowe i partia ${ }^{26}$.

Przekaz tradycji zawiera - w różnych proporcjach — kilka składników. Należy do nich obraz czasu, złożony z opisu wydarzeń, nazwania i charakterystyki aktorów (jednostek, grup, zbiorowości lub instytucji) wraz z ich motywacjami i powodami działania. Towarzyszą temu oceny wydarzeń oraz wiedza na temat odpowiedniej, przynoszącej korzyści i zadowalającej osoby trzecie kontekstualizacji. Wszystko to jest konsekwencją językowych konwencji, skryptów kulturowych, wzorców interpretacyjnych, toposów, struktur fabularnych, a także zależnych od sytuacji uwarunkowań społecznych i psychologicznych.

26 Sabine Moller, Vielfache Vergangenheit. Öffentliche Erinnerungskulturen und Familienerinnerungen an die NS-Zeit in Ostdeutschland, Tübingen 2003. 


\section{RZUT OKA W PRZYSZŁOŚĆ}

Zachodnioeuropejskie badania nad przekazem pamięci, tak zresztą jak badania nad pamięcią zbiorową w ogóle, uciekają od tematu „narodowy socjalizm i druga wojna światowa”. Na przykład w Luksemburgu w ramach interdyscyplinarnego projektu bada się procesy transmisji w kontrastowo odmiennych środowiskach ${ }^{27}$. Pamiętanie, wspomnienia migrantów różnych generacji należących do różnych grup społecznych, na przykład robotników stalowni i chłopów, tylko w niewielkim stopniu uwzględniają odniesienia do wojny. Chodzi raczej o to, jakie znaczenie mają wyobrażenia dotyczące prywatnej ojczyzny, integracji, konstrukcji biografii zawodowych ważne dla specyficznie różnych wspólnot pamięci. Poza taką zmianą tematu badań i nadaniem im charakteru porównawczego istnieje jeszcze wiele innych potencjalnych możliwości badawczych. Dotychczasowe studia są skupione na bardzo wąsko rozumianej rodzinie, inne konstelacje ważnych dla pamięci peers (na przykład przyjaciele) zostały zbadane tylko $\mathrm{w}$ niewielkim stopniu. Poszerzeniu pola badawczego musi towarzyszyć pogłębienie badań, przede wszystkim w sferze metod, czyli między innymi wniknięcie $\mathrm{w}$ społeczny wymiar pamięci $\mathrm{z}$ wykorzystaniem koncepcji etnograficznych. Karoline Tschuggnall wykazała ponadto, jak płodne jest spojrzenie na dyscypliny pokrewne, takie jak psychologia dyskursu i narratologia ${ }^{28}$. Mogą być rozbudowywane nawiązania do klasycznych badań psychospołecznych, na przykład w postaci badania łańcuchów narracyjnych $w$ ramach badań nad przekazem opowieści ${ }^{29}$, podobnie jak poszukiwania głównych aspektów pamięci narracyjnej i komunikacyjnej, czyli — jak się wydaje — określone tryby opowiadania ${ }^{30}$. W niemal wszystkich dziedzinach badań nad pamięcią, zwłaszcza nad pamięcią zbiorową, brakuje metastudiów lub studiów poświęconych literaturze. Przyszłością badań nad tradycją i jej przekazem jest przede wszystkim samo zagadnienie „przyszłości”, czyli to, jakie znaczenie dla interpretowania przeszłości mają oczekiwania wobec przyszłości i jej koncepcje ${ }^{31}$. Pilnie potrzebna jest rozbudowa wszelkich form badań recepcji jako badań podstawowych, zwłaszcza filmowych reprezentacji przeszłości i ich wpływu

27 Por. http://www.fnr.lu/en/Grants-Activities/Research-Programmes/Projects/Collective-Exp eriences,-Intergenerational-Memory-and-Identity-Constructions-in-Luxembourg-Witnesses-ofWorld-War-II,-Peasants,-Industrial-Workers,-Immigrants-LUX-ID [31.03.2011].

${ }^{28}$ Karoline Tschuggnall, Sprachspiele des Erinnerns. Lebensgeschichte, Gedächtnis und Kultur, Giessen 2004

29 Torsten Koch, Harald Welzer, Weitererzählforschung. Zur seriellen Reproduktion erzählter Geschichten, w: Leben - Erzählen. Beiträge zur Biographie- und Erzählforschung. Festschrift für Albrecht Lehmann zum 65. Geburtstag, Thomas Hengartner, Brigitta Schmidt-Lauber (red.), Berlin 2005, s. 165-182.

30 Christian Gudehus, Remembering WWII in Europe - Structures of Remembrance, w: Dynamics of Memory in the New Europe, Eric Langenbacher, William Niven, Ruth Wittlinger (red.), New York-Oxford 2011.

${ }^{31}$ Lesley Bleakney, Harald Welzer, Strukturwandel des Familiengedächtnisses. Ein Werkstattbericht, „Familiendynamik” 2009, t. 34, z. 1, s. 2-9. 
na powstawanie obrazów historii na różnych płaszczyznach. Wyniki dotychczasowych badań sugerują, że filmy, podobnie jak inne oferty interpretacyjne, są przyswajane zgodnie $z$ indywidualnymi dyspozycjami. Jeden i ten sam produkt może być podstawą zarówno bardzo emocjonalnych autotematyzacji, jak i refleksji nad konstruktywistycznym charakterem interpretacji historii 32 .

Jak pokazuje rzut oka na przeszłość, teraźniejszość i przyszłość młodych jeszcze badań nad tradycją i jej przekazem, ich koncepcja stale się rozwija, ma wymiar transdyscyplinarny i wykazuje otwartość na inne dyscypliny, metody i teorie.

Tłumaczyła Elżbieta Kaźmierska

\section{ON THE THEORY AND METHOD OF STUDYING CULTURAL COMMUNICATION}

\section{Sum mary}

Issues concerning history and the construction of images of the past have always been of importance for the self-identification of individuals, social groups, governing institutions, states, and especially nations. Currently, two trends can be noticed, which may seem antagonistic, but actually condition and shape each other: renegotiating and redefining national historical narratives as well as the opening of national historiography to transnational or globalized perspective. National images and historical myths tend to increase integrity among the members of European communities only to a limited degree, and their importance to the highly normatively-oriented structures of the so called European identity - based on still less credible European memory, perceived by means of also normatively-oriented publicity - is rather doubtful. As a result, a scientific discipline has evolved, which studies subjective means of internalizing and utilizing the past rather than public aspects of culture and memory. The discipline involves the studies of tradition and passing thereof, which are rooted in the institution of qualitative sociological research. This article is about the scope and methods of such studies which are focused on how to tell about the past.

\section{Key words/słowa kluczowe}

memory / pamięć; telling about the past / opowiadanie przeszłości; national identity / tożsamość narodowa; European identity / tożsamość europejska

32 Christian Gudehus, Stewart Anderson, współpraca David Keller, Understanding Hotel Rwanda: A Reception Study, „Memory Studies” 2010, t. 3, z. 4, s. 344-363. 